Running head: Attitudes towards alcohol-related absence and presenteeim

Attitudes towards alcohol-related sickness absence and presenteeism: Differences across subgroups of the population?

Line Schou $^{1 *}$, Inger Synnøve Moan ${ }^{2}$ and Elisabet Storvoll ${ }^{2}$

${ }^{1}$ University of Oslo, Department of Sociology and Human Geography, PO Box 1096

Blindern, 0317 Oslo, Norway.

${ }^{2}$ Norwegian Institute of Public Health, Department of Alcohol, Drug and Tobacco Research, PO Box 4404 Nydalen, 0403 Oslo, Norway

*Address correspondence to:

Line Schou, University of Oslo, Department of Sociology and Human Geography, PO Box 1096 Blindern, 0317 Oslo, Norway. Tel: +47 97016841. E-mail: line.schou@gmail.com 


\title{
Attitudes towards alcohol-related sickness absence and presenteeism: Differences across subgroups of the population?
}

\begin{abstract}
Background: More knowledge is needed to understand costly behaviours such as absence from work or reduced efficiency at work due to alcohol. The aim of this study was: (i) to map employees' attitudes towards alcohol-related sickness absence and presenteeism, and (ii) to examine how these attitudes vary across subgroups of the population.

Methods: Data stem from a web-survey among 18-69 year old Norwegians $(\mathrm{N}=1407)$. The respondents evaluated six situations with alcohol-related sickness absence and presenteeism. The employees' own drinking habits, alcohol-related sickness absence and presenteeism were mapped.
\end{abstract}

Results: Attitudes towards alcohol-related absence were more restrictive than attitudes towards presenteeism. Both behaviours were condemned more strongly with frequent occurrence. Employees with a high intoxication frequency and/or own experience with these behaviours were more tolerant. Women were less tolerant of alcohol-related absence than men, and employees with a higher educational level were less tolerant of alcohol-related presenteeism than those with a low educational level. The other variables were not significant controlled for all other variables.

Conclusion: Alcohol-related sickness absence and presenteeism are generally not tolerated among Norwegian employees, unless it occurs very infrequently. Employees who were frequently intoxicated and who reported having had alcohol-related absence and presenteeism themselves were more tolerant.

Keywords: alcohol-related sickness absence, presenteeism, attitudes 


\section{Introduction}

Alcohol use can cause sickness absence, both long-term (Upmark,1999) and short-term (McFarlin \& Fals-Stewart, 2002), (for review, see Schou \& Moan, 2015). Other studies have found alcohol use to be among the risk factors that increase inefficiency at work (hereafter “presenteeism”) (Cooper \& Dewe, 2008; Edvardsen et al., 2014; Edvardsen et al., 2015; Gjerde et al., 2010; Holden et al., 2011; Shi et al., 2013). Costs related to alcohol use for workplaces are consistently found to be high, and it has been estimated that sickness absence and presenteeism account for the largest fractions of the work-related costs (Gjelsvik, 2004; Laslett et al., 2010).

In order to curb the negative effect alcohol use has on workplaces, more knowledge is needed to understand the mechanisms behind norm deviating behaviour such as alcoholrelated sickness absence and presenteeism. In behavioural research, attitudes towards the behaviour are regarded to be among the most important indicators of how people will act (e.g., Ajzen, 1991). Attitudes are defined as "a psychological tendency that is expressed by evaluating a particular entity with some degree of favor or disfavor" (Eagly \& Chaiken, 1993, page 1).

In Norway, showing up and doing your work is a rather strong norm. High participation in the labour force and not too much absence are often referred to as necessities in order to maintain the welfare state e.g. (NOU, 2004). Nevertheless, alcohol-related sickness absence is not uncommon.

The alcohol consumption of individual employees, including whether they drink on the job or show up with a hangover, have been found to be influenced by drinking norms in the work place (Ames et al., 2000). There is, however, to our knowledge, no previous research about employees' attitudes towards alcohol-related sickness absence and presenteeism. Thus our study mapping such attitudes will provide new knowledge. Such information is useful for preventive efforts in this context.

Subgroup differences in attitudes

According to well-known attitude-behaviour models, e.g. the Theory of Planned Behaviour (Ajzen, 1991), attitudes towards a behaviour are assumed to be a result of among other things socio-demographic characteristics such as age, gender and educational level. Moreover, such theories propose that attitudes are formed through past experience with the behaviour. In addition to previous sickness absence and presenteeism due to alcohol, one can expect 
drinking habits per se to be of relevance. The more people drink themselves, the more liberal attitudes they are expected to have toward both alcohol use and related problems (Caetano \& Clark, 1999).

To our knowledge, no previous studies have examined group differences in attitudes towards alcohol-related sickness absence and presenteeism. However, previous studies have found alcohol-related sickness absence to be more prevalent among men (Schou et al., 2014; Edvardsen et al., 2015), younger age groups (Craig et al. 2012; Roche et al., 2008), those with a low level of education (Johansson, Bockerman, \& Uutela, 2009) and income (Schou \& Birkelund, 2015), and among those with a high consumption of alcohol (Schou et al., 2014), Alcohol-related presenteeism have been found to be more prevalent among men (Edvardsen et al., 2015; Norwegian Directorate of Health, 2006) and younger employees (Craig et al., 2012).

\begin{abstract}
Aims
The aims of this study were: (i) To map employees' attitudes towards alcohol-related sickness-absence and presenteeism, and (ii) to examine how these attitudes vary across subgroups of the population, i.e. according to gender, age, educational level, income, full time versus part time job - and according to the respondents' own drinking habits as well as their experience with alcohol-related sickness absence and presenteeism.
\end{abstract}

\title{
Methods
}

Participants and procedure

The data stem from a web-survey conducted among respondents in Norway in 2013. The study was commissioned by The Norwegian Institute for Alcohol and Drug Research (SIRUS) $^{1}$ from TNS Gallup. A sample of 4000 18-69 year olds was drawn from an online panel comprising more than 50000 citizens. The sample was stratified according to figures from Statistics Norway on gender, age (4 groups), geographic region (4 groups), and education (2 groups). Of the original sample, 2182 (55\%) participated. For a more detailed description of the web-survey see (Rise \& Halkjelsvik, 2015). The net sample was weighted

\footnotetext{
${ }^{1}$ SIRUS merged with The Norwegian Institute of Public Health 1 January 2016.
} 
to reflect the distribution of gender, age and education in the population. All reported findings were calculated in the weighted sample.

A few respondents who reported that they were older than 69 years of age were excluded from the analyses $(\mathrm{N}=11)$. We were primarily interested in the attitudes of employees, thus only respondents who were employed (full or part time) were included in the analyses $(\mathrm{N}=1407)$. Of this sample, $47.2 \%$ were women and the average age was 43.69 years $(\mathrm{SD}=12.05)$. A higher educational level was reported by $38.1 \%$ of the respondents.

\section{Measures}

Attitudes towards alcohol-related sickness absence and presenteeism: The respondents were asked to evaluate four different situations describing alcohol-related absence and two situations describing presenteeism due to alcohol (see Table 1 for wording of the items). The response scales were: completely unproblematic (coded 4), quite unproblematic (3), quite problematic (2) and very problematic (1). Based on the responses, each respondent were given a mean score ranging from 1-4 on each index. The higher the score, the higher the tolerance for alcohol-related absence or presenteeism. Cronbach's Alpha $=0.75$ for attitude towards alcohol-related absence, and the two items comprising the attitude towards presenteeism index were strongly correlated 0.65 . Thus, the internal consistency of the attitude measures were satisfactory (cf., Nunnally, 1978). Because of missing responses of more than one question, 1 person did not get a score on one of the indices. Thus, the net sample for the present paper was 1406 .

Demographic variables: Gender, age (4 categories), education (higher/lower), income (4 categories), and working full time versus part time. See Table 2 for more details about the categories of each variable.

Own alcohol use the past 12 months: Drinking frequency was divided into 7 categories: Never (coded 0), one or a few times last year (1), once a month (2), 2 - 3 times a month (3), once a week (4), 2 - 3 days a week (5), 4 days a week or more (6). Intoxication frequency was divided into 5 categories: Never (coded 0), one or a few times last year (1), once a month (2), $2-3$ times a month (3), one day a week or more (4).

Own sickness absence due to alcohol the past 12 months. Respondents were asked if they had been absent from work 1 - 3 hours $(n=24,1.8 \%)$ and if they had been absent one or more days $(n=16,1.2 \%)$. The categories were combined in one dichotomous variable: Any absence (coded 1 ) versus no absence (0). 
Own presenteeism at work due to alcohol the past 12 months. Respondents were asked if they had been present at work, but felt unfocused and less efficient than usual $(\mathrm{n}=246,17,4 \%) .0$ times (coded 0), $1-2$ times (1), 3 or more times (2).

\section{Statistical analyses}

First, the mean scores of each item mapping attitudes towards alcohol-related absence and presenteeism were calculated (see Table 1). Second, the mean scores of the two indices for attitudes towards absence and presenteeism were calculated, for the whole sample and for various subgroups, (see Table 2). Third, we calculated Pearson's correlations between variables included in the regression analyses (see Table 3). Fourth, linear regression analyses, with attitudes towards alcohol-related absence and presenteeism as outcomes in separate models, were conducted (see Table 4).

\section{Results}

Table 1 shows that people's attitudes were more restrictive towards alcohol-related absence $($ mean scores $=1.07-2.11)$ than towards presenteeism $($ mean scores $=2.16$ and 3.02).

Moreover, both attitudes became more restrictive with increased frequency of such behavior, e.g., being absent from work one day a year due to drinking alcohol the day before versus being absent twice a month.

Table 2 shows the mean score on the attitude indices in the sample as a whole and across subgroups of the population. In the sample as a whole, attitudes towards alcoholrelated presenteeism were less restrictive than attitudes towards absence due to alcohol, mean scores were 2.59 and 1.50 respectively.

Bivariate analyses showed that attitudes towards alcohol-related absence were more positive with increasing intoxication frequency, more positive among men than women, and among those who reported having such absence themselves. Attitudes towards presenteeism were more positive with increasing frequencies of both drinking and intoxication, among men than women and among those who reported experiencing reduced efficiency several times themselves (see Table 2). 
Table 1. Items measuring attitudes towards alcohol-related sickness absence and presenteeism. Proportion (\%) that reported that the following behaviours were problematic/unproblematic $(\mathrm{N}=1406)$.

\begin{tabular}{|c|c|c|c|c|c|}
\hline \multirow[b]{2}{*}{$\begin{array}{l}\text { Attitudes towards } \\
\text { alcohol-related } \\
\text { sickness absence }\end{array}$} & \multicolumn{4}{|c|}{$\%$} & \multirow{2}{*}{$\begin{array}{l}\text { Mean } \\
(\mathrm{SD})\end{array}$} \\
\hline & $\begin{array}{l}\text { Very } \\
\text { problematic }\end{array}$ & $\begin{array}{l}\text { Quite } \\
\text { problematic }\end{array}$ & $\begin{array}{l}\text { Quite } \\
\text { unproblematic }\end{array}$ & $\begin{array}{c}\text { Completely } \\
\text { unproblematic }\end{array}$ & \\
\hline $\begin{array}{l}\text { An office employee } \\
\text { is two hours late for } \\
\text { work twice a year } \\
\text { due to drinking } \\
\text { alcohol the night } \\
\text { before }\end{array}$ & 29.7 & 36.6 & 26.8 & 7.0 & $\begin{array}{c}2.11 \\
(0.91)\end{array}$ \\
\hline $\begin{array}{l}\text { An office employee } \\
\text { is two hours late for } \\
\text { work twice a month } \\
\text { due to drinking } \\
\text { alcohol the night } \\
\text { before }\end{array}$ & 64.7 & 30.8 & 4.1 & 0.4 & $\begin{array}{r}1.40 \\
(0.59)\end{array}$ \\
\hline $\begin{array}{l}\text { An office employee } \\
\text { is absent from work } \\
\text { all day twice a year } \\
\text { due to drinking } \\
\text { alcohol the night } \\
\text { before }\end{array}$ & 66.8 & 26.1 & 6.2 & 1.0 & $\begin{array}{c}1.41 \\
(0.65)\end{array}$ \\
\hline $\begin{array}{l}\text { An office employee } \\
\text { is absent from work } \\
\text { all day twice a } \\
\text { month due to } \\
\text { drinking alcohol the } \\
\text { night before }\end{array}$ & 93.5 & 5.7 & 0.5 & 0.2 & $\begin{array}{r}1.07 \\
(0.30)\end{array}$ \\
\hline $\begin{array}{l}\text { Attitudes towards } \\
\text { presenteeism }\end{array}$ & $\begin{array}{c}\text { Very } \\
\text { problematic }\end{array}$ & $\begin{array}{c}\text { Quite } \\
\text { problematic }\end{array}$ & $\begin{array}{c}\text { Quite } \\
\text { unproblematic }\end{array}$ & $\begin{array}{c}\text { Completely } \\
\text { unproblematic }\end{array}$ & $\begin{array}{l}\text { Mean } \\
\text { (SD) }\end{array}$ \\
\hline $\begin{array}{l}\text { An office employee } \\
\text { is less efficient at } \\
\text { work than usual } \\
\text { twice a year due to } \\
\text { drinking alcohol the } \\
\text { night before }\end{array}$ & 5.2 & 22.3 & 38.0 & 34.5 & $\begin{array}{l}3.02 \\
(0.88)\end{array}$ \\
\hline $\begin{array}{l}\text { An office employee } \\
\text { is less efficient at } \\
\text { work than usual } \\
\text { twice a month due to } \\
\text { drinking alcohol the } \\
\text { night before }\end{array}$ & 20.7 & 48.2 & 25.2 & 5.9 & $\begin{array}{r}2.16 \\
(0.82)\end{array}$ \\
\hline
\end{tabular}


Table 2. Mean score on attitudes towards alcohol-related sickness absence and presenteeism (scale 1-4) for various subgroups.

\begin{tabular}{|c|c|c|c|c|c|c|}
\hline \multicolumn{3}{|l|}{ Dependent variable } & \multicolumn{2}{|c|}{ Sickness absence } & \multicolumn{2}{|c|}{ Presenteeism } \\
\hline Groups & $\mathrm{N}$ & $\%$ & $\mathrm{M}$ & $\mathrm{SD}$ & $\mathrm{M}$ & $\mathrm{SD}$ \\
\hline All & 1406 & 100.0 & 1.50 & 0.49 & 2.59 & 0.77 \\
\hline Gender & & & $\mathrm{F}=14.71^{* * *}$ & & $\mathrm{~F}=5.46^{*}$ & \\
\hline Male & 743 & 52.8 & 1.55 & 0.51 & 2.64 & 0.79 \\
\hline Female & 663 & 47.2 & 1.45 & 0.46 & 2.54 & 0.74 \\
\hline Age & & & $\mathrm{F}=0.56^{\mathrm{ns}}$ & & $\mathrm{F}=1.74^{\mathrm{ns}}$ & \\
\hline 18-29 years & 225 & 16.0 & 1.53 & 0.54 & 2.70 & 0.81 \\
\hline $30-44$ years & 544 & 38.7 & 1.51 & 0.49 & 2.57 & 0.77 \\
\hline 45-59 years & 499 & 35.5 & 1.48 & 0.49 & 2.56 & 0.75 \\
\hline 60 years or older & 138 & 9.8 & 1.49 & 0.43 & 2.58 & 0.76 \\
\hline Level of education & & & $\mathrm{F}=0.00^{\mathrm{ns}}$ & & $\mathrm{F}=1.91^{\mathrm{ns}}$ & \\
\hline Junior/senior high school & 870 & 61.9 & 1.50 & 0.50 & 2.61 & 0.79 \\
\hline University & 536 & 38.1 & 1.50 & 0.48 & 2.55 & 0.74 \\
\hline Income $($ missing $=139)$ & & & $\mathrm{F}=1.19^{\mathrm{ns}}$ & & $\mathrm{F}=0.55^{\mathrm{ns}}$ & \\
\hline Less than $200000 \mathrm{NOK}$ & 41 & 3.2 & 1.63 & 0.63 & 2.67 & 0.83 \\
\hline $200000-499000 \mathrm{NOK}$ & 757 & 59.8 & 1.50 & 0.50 & 2.58 & 0.79 \\
\hline 500 000-799 $000 \mathrm{NOK}$ & 390 & 30.8 & 1.51 & 0.48 & 2.63 & 0.74 \\
\hline $800000 \mathrm{NOK}$ or more & 78 & 6.2 & 1.46 & 0.45 & 2.57 & 0.80 \\
\hline Employment & & & $\mathrm{F}=1.41^{\mathrm{ns}}$ & & $\mathrm{F}=2.38^{\mathrm{ns}}$ & \\
\hline Full time & 1193 & 84.8 & 1.51 & 0.49 & 2.60 & 0.77 \\
\hline Part time & 213 & 15.2 & 1.46 & 0.51 & 2.51 & 0.80 \\
\hline Drinking frequency & & & $\mathrm{F}=1.73^{\mathrm{ns}}$ & & $\mathrm{F}=9.00^{* * *}$ & \\
\hline Not drinking & 81 & 5.8 & 1.41 & 0.54 & 2.15 & 0.66 \\
\hline A few days & 269 & 19.2 & 1.47 & 0.50 & 2.45 & 0.82 \\
\hline Once a month & 178 & 12.7 & 1.47 & 0.44 & 2.57 & 0.76 \\
\hline 2-3 times a month & 301 & 21.4 & 1.50 & 0.49 & 2.61 & 0.78 \\
\hline About once a week & 318 & 22.6 & 1.56 & 0.51 & 2.71 & 0.71 \\
\hline 2-3 times a week & 212 & 15.1 & 1.49 & 0.48 & 2.68 & 0.75 \\
\hline 4 days a week or more & 47 & 3.3 & 1.55 & 0.46 & 2.85 & 0.79 \\
\hline Intoxication frequency & & & $\mathrm{F}=5.08^{* * *}$ & & $\mathrm{~F}=12.78^{* * *}$ & \\
\hline No episodes & 379 & 27.0 & 1.43 & 0.46 & 2.39 & 0.78 \\
\hline
\end{tabular}




\begin{tabular}{|c|c|c|c|c|c|c|}
\hline A few times & 668 & 47.5 & 1.49 & 0.48 & 2.61 & 0.75 \\
\hline Once a month & 174 & 12.3 & 1.55 & 0.55 & 2.68 & 0.74 \\
\hline 2-3 times a month & 121 & 8.6 & 1.60 & 0.51 & 2.86 & 0.73 \\
\hline Once a week or more often & 65 & 4.6 & 1.64 & 0.53 & 2.83 & 0.78 \\
\hline $\begin{array}{l}\text { Absent from work } \\
(\text { missing }=9)\end{array}$ & & & $=23.82^{* * *}$ & & & \\
\hline No episodes & 1367 & 97.9 & 1.49 & 0.49 & - & \\
\hline At least once & 30 & 2.1 & 1.93 & 0.60 & - & \\
\hline Presenteeism & & & & & $\mathrm{F}=44.28^{* * *}$ & \\
\hline No episodes & 1161 & 82.5 & - & & 2.50 & 0.77 \\
\hline 1-2 times & 186 & 13.2 & - & & 2.95 & 0.67 \\
\hline 3 times or more & 60 & 4.2 & - & & 3.12 & 0.58 \\
\hline
\end{tabular}

\section{Correlations}

Table 3 shows that the correlation between attitudes toward alcohol-related sickness absence and attitudes toward presenteeism was 0.52 , which is considered to be large in terms of effect size (Cohen, 1988). In the regression analyses, these two variables are outcomes in two different models. The variables that were significantly correlated with attitude towards alcohol-related absence were, by order of correlation strength: self-reported alcohol-related absence, intoxication frequency and gender. In terms of effect size, the correlations were generally small, i.e. around 0.1 (Cohen, 1988). The variables that were significantly correlated with attitude towards presenteeism were, by order of correlation strength: self-reported presenteeism due to alcohol, intoxication frequency and gender, Also here, the correlations were generally small in terms of effect size, the largest being 0.22 . 


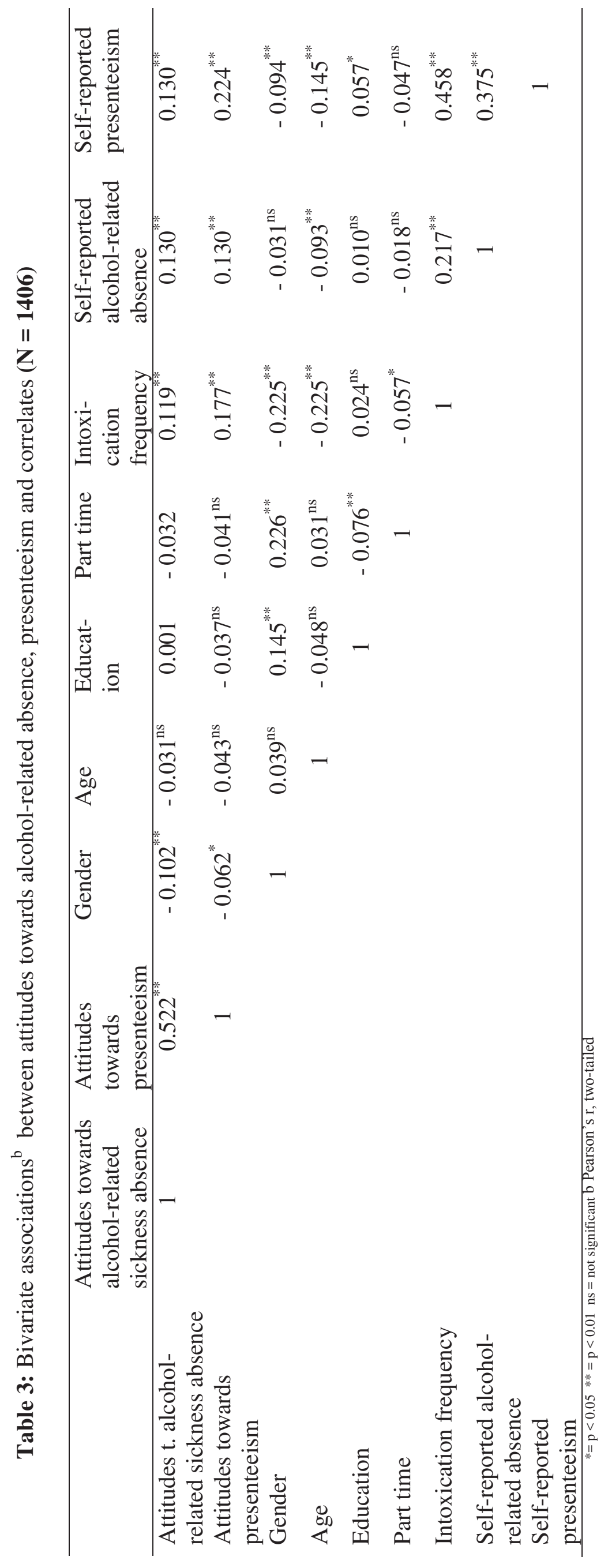




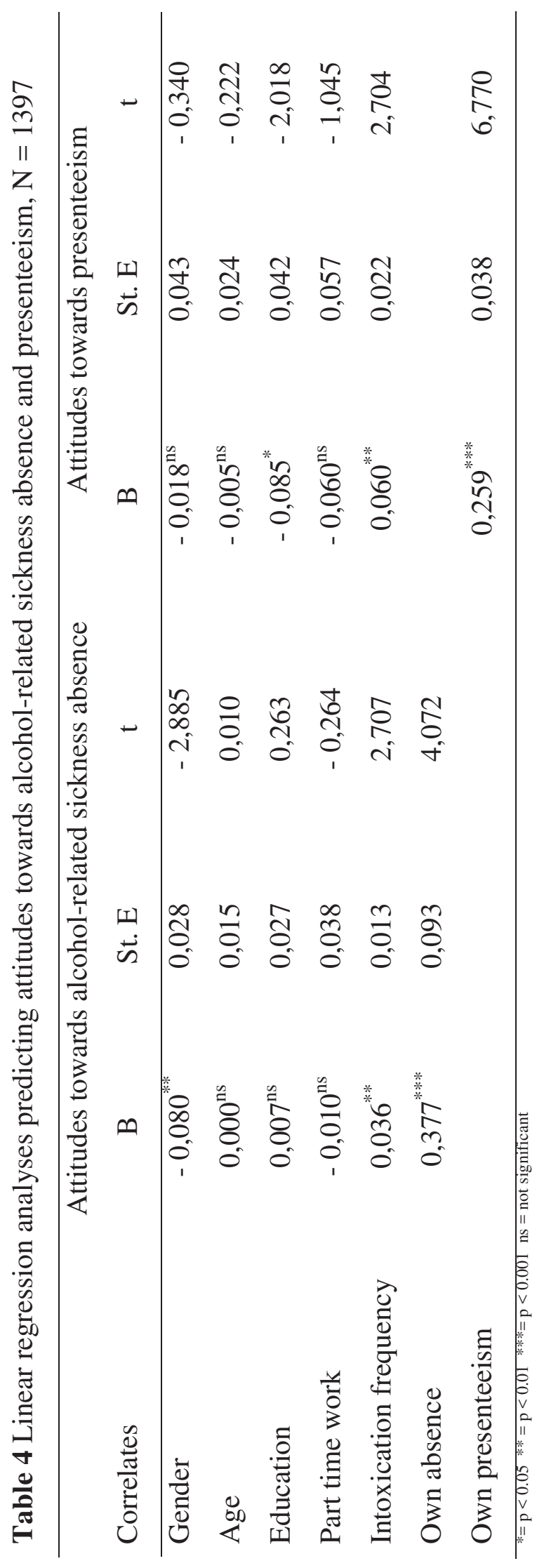


Regression analyses

Drinking frequency and intoxication frequency were strongly correlated (0.51). We therefore chose to include only intoxication frequency in the regression analyses. Due to a high rate of missing values, income was also excluded from the regression analyses.

Regression analyses in which the effect of each correlate was controlled for the effect of all other correlates, are shown in Table 4. Women were significantly more restrictive towards alcohol-related absence than men. The attitude towards such absence was more positive with a higher intoxication frequency and among those who reported having experienced alcohol-related absence themselves. The other correlates were not significant. The attitude towards presenteeism was more restrictive among those with a higher education and more positive among those who had experienced presenteeism themselves and among those with a higher intoxication frequency. The other correlates were not significant.

\section{Discussion}

This study showed that employees' attitudes towards alcohol-related absence and presenteeism generally were restrictive, but that alcohol-related presenteeism was tolerated more than absence, and both behaviours were accepted by many employees if occurring only very seldom. Demographic differences were found; men were more tolerant of alcohol-related absence than women, and employees with a low educational level were more tolerant of alcohol-related presenteeism than those with a high educational level. Employees who reported having a high intoxication frequency and/or experience of their own with alcoholrelated absence and presenteeism, were more tolerant of these behaviours.

Possible explanations for attitudes found in the general sample The findings which suggest that alcohol-related presenteeism is tolerated more than absence may be in line with the social norm requiring people to show up and do their work (NOU, 2004). In cases of alcohol-related presenteeism, people have shown up at work even if having hangover symptoms, and may be seen as making an effort to behave as required and not having lost control completely. Being present - in spite of feeling ill, may be seen as a milder breach of the norm. In some work places, there may even be tolerance of some presenteeism 
due to alcohol among colleagues. The fact that more people reported having had alcoholrelated presenteeism the past 12 months ( $17.4 \%$ reported 1 or more times) than alcoholrelated absence in the same period (2.1\% reported absence part of the day or longer) partly support this notion.

The almost full agreement on condemning these behaviours if occurring frequently, can reflect that people may be allowed to make a mistake once or twice - drinking to intoxication on certain occasions is part of the traditional Norwegian drinking pattern (Horverak \& Bye, 2007) - but frequent absence or presenteeism due to alcohol is seen as a serious problem. In those cases, people may be seen as having lost control of their alcohol use and causing trouble both for themselves and others.

\section{Subgroup differences in attitudes}

The most important demographic factor influencing attitudes towards alcohol-related sickness absence was gender. Women were generally more restrictive than men, even when other factors, including own drinking pattern and experience with this phenomenon, were controlled for. This is in line with previous research showing gender role differences in relation to alcohol. Cultural expectations and traditions require women to control their own alcohol consumption and also to influence men to control theirs (de Visser \& McDonnell, 2012; Neve et al., 1997). Men drink more alcohol than women, both in terms of total consumption and frequency of heavy drinking, in all societies surveyed (Craig et al., 2012; Wilsnack et al., 2000 ). Although great changes have taken place in the last decades, and women's alcohol consumption has increased steadily, it is not surprising that women condemn alcohol-related harm more strongly. This reasoning is also consistent with the findings that alcohol-related sickness absence and presenteeism are more common among men than women (Edvardsen et al., 2015; Schou et al., 2014).

It is perhaps a bit surprising that there was no difference in tolerance between age groups, neither when own experience was controlled for or in the univariate analyses. This is not in line with previous research which found higher rates of alcohol-related absence among young people (Roche et al., 2008). This connection may be weaker in young people, they do not seem to be more tolerant of alcohol-related presenteeism and absence, even if they experience it slightly more often. This may be connected to ideas of binge drinking among young people as a temporary phase, and episodes of alcohol-related presenteeism and absence among young people as exceptions and not something they will continue to do. 
There was no significant difference in attitudes towards alcohol-related absence according to education. Alcohol-related presenteeism, however, was more strongly condemned among those with a higher education. Reduced efficiency caused by a hangover may be more evident while doing work which require concentration and abstract thinking. People with a higher education may also more often see their work as personally fulfilling and a source of personal development, and may therefore take offence if colleagues appear not to value their work by showing up with a hangover.

People who frequently drink to intoxication and/or have experienced alcohol-related absence or presenteeism themselves, are found to be more tolerant. This shows the importance of past behaviour and experiences. This is in line with attitude-behaviour models which assume past experience with a type of behaviour to be important for attitudes towards that behaviour (e.g., Ajzen, 1991). However, this association between attitudes and actions may be explained in two ways; either people act as they do because their attitudes allow them to - or they adjust their attitudes in order to avoid cognitive dissonance (Festinger, 1957), when failing to act the way they think they are supposed to. In this instance, people could have alcohol-related sickness absence or presenteeism because they have tolerant attitudes towards this behaviour, or because they changed their restrictive attitudes after failing to keep their drinking from interfering with work. With cross-sectional data, we cannot tell which came first, the attitudes or the actions. Either way, attitudes may be an important indicator of future behaviour.

Methodological considerations and suggestions for future research

To our knowledge, this is the first study to explore employees' attitudes towards alcoholrelated absence and presenteeism. Attitudes towards these two different types of alcoholrelated harm are mapped, as well as their correlations with several other variables, including the employees' own experiences with these phenomena. The results from this study can contribute knowledge relevant for preventive efforts targeted at these types of alcohol-related harm.

The sample was stratified to reflect the population figures on gender, age, geographic region and education. However, the response rate was $55 \%$. A high intoxication frequency and/or experience with alcohol-related absence and presenteeism is likely to be more prevalent among non-responders (Johnson, 2014), and this may also affect estimates of attitudes, so that tolerance of alcohol-related absence and presenteeism among Norwegian 
employees may be somewhat greater than measured in this study. However, this is less likely to affect the correlations between attitudes and other variables (Aaberge \& Laake, 1984).

There may also be other important correlates of attitudes towards alcohol-related absence and presenteeism, than those included in this study. Other possible correlates are norms in the work place and the attitudes of colleagues, which are likely to influence both individual attitudes and the actions of individual employees directly. This could be examined with multi-level analysis, in which companies or work places could form level 2 and individual employees level 1. The effect of informal norms and formal policies on the company level versus individual experiences and socio-demographic characteristics could thus be examined.

Since this study uses cross-sectional data, it is not possible to assess whether attitudes predict actions or if actions influence attitudes over time. Future research on longitudinal data could examine the association between attitudes towards alcohol-related absence and presenteeism and one's own actions more carefully.

\section{Conclusions}

Frequently occurring alcohol-related sickness absence and presenteeism are generally not tolerated among Norwegian employees. However, many tolerate such behaviour, especially presenteeism, if infrequent. Women were more restrictive towards alcohol-related absence than men, and respondents with a high educational level were more restrictive towards alcohol-related presenteeism than employees with a low level of education. However, the most important indicator of attitudes seem to be past behaviour, both in terms of people's own drinking behaviour and their experience with alcohol-related absence and presenteeism.

\section{Declaration of Interest}

The authors report no conflicts of interest. 


\section{References}

Ajzen, I. (1991). The theory of planned behavior. Organizational Behavior and Human Decision Processes, 50, 179-211.

Ames, G. M., Grube, J. W., \& Moore, R. S. (2000). Social control and workplace drinking norms: A comparison of two organizational cultures. Journal of Studies on Alcohol, 61(2), 203-219.

Caetano, R. \& Clark, C. (1999) Trends in situational norms and attitudes toward drinking among whites, blacks and hispanics: 1984 - 1995 Drug and Alcohol Dependence 54(1), 45-56

Cohen, J. (1988) Set Correlation and Contingency Tables. Applied Psychological Measurement 12 (4). Downloaded from the Digital Conservancy at the University of Minnesota, http://purl.umn.edu/93227

Cooper, C., \& Dewe, P. (2008). Well-being - absenteeism, presenteeism, costs and challenges. [Editorial]. Occupational Medicine, 58(8), 522-524.

Craig, D. G., Dakkak, M., Gilmore, I. T., Hawkey, C. J., Rhodes, J. M., \& Sheron, N. (2012). A drunk and disorderly country: a nationwide cross-sectional survey of alcohol use and misuse in Great Britain. Frontline Gastroenterology, 3, 57-63.

de Visser, R. O., \& McDonnell, E. J. (2012). 'That's OK. He's a guy': a mixed-methods study of gender double-standards for alcohol use. Psychology and Health, 27(5), 618-639.

Eagly, A. H., \& Chaiken, C. (1993). The psychology of attitudes. Fort Worth, TX: Harcourt, Brace \& Jovanovich.

Edvardsen, H. M. E., Karinen, R., Moan, I. S., Øiestad, E. L., Christophersen, A. S., \& Gjerde, H. (2014). Use of alcohol and drugs among health professionals in Norway: a study using data from questionnaires and samples of oral fluid. Journal of occupational medicine and toxicology, 9:8 (http://www.occupmed.com/content/9/1/8).

Edvardsen, H. M. E., Moan, I. S., Christophersen, A. S., \& Gjerde, H. (2015). Use of alcohol and drugs by employees in selected business areas in Norway: a study using oral fluid testing and questionnaires. Journal of occupational medicine and toxicology, 10:46

Festinger, L. (1957). A Theory of Cognitive Dissonance. California: Stanford University Press.

Gjelsvik, R. (2004). Utredning av de samfunnsmessige kostnadene relatert til alkohol [Estimation of society's costs related to alcohol] Notatserie i helseøkonomi (Vol. 7). Bergen.

Gjerde, H., Christophersen, A. S., Moan, I. S., Yttredal, B., Walsh, J. M., Normann, P. T., \& Morland, J. (2010). Use of alcohol and drugs by Norwegian employees: a pilot study using questionnaires and analysis of oral fluid. Journal of occupational medicine and toxicology, 5:13.

Helsedirektoratet. (2006). Resultater fra Synovate MMI sin spфrreunders $\phi$ kelse sommeren 2006 [The Directorate of Health. Results from Synovate MMI's survey in the summer of 2006] Oslo.

Horverak, O., \& Bye, E. K. (2007). Det norske drikkemønsteret - En studie basert på intervjudata fra 1973 - 2004 [The Norwegian drinking pattern - A study based on interview data from 1973 - 2004]. Oslo: SIRUS, Norwegian Institute for Alcohol and Drug Research

Holden, L., Scuffham, P. A., Hilton, M. F., Ware, R. S., Vecchio, N., \& Whiteford, H. A. (2011). Health-related productivity losses increase when the health condition is comorbid with psychological distress: findings from a large cross-sectional sample of working Australians. BMC Public Health, 11, 417. 
Johansson, E., Bockerman, P., \& Uutela, A. (2009). Alcohol consumption and sickness absence: evidence from microdata. European Journal of Public Health, 19(1), 19-22.

Johnson TP. Sources of Error in Substance Use Prevalence Surveys. International Scholarly Research Notices, 2014, 21.

Laslett, A. M., Catalano, P., Chikritzhs, Y., Dale, C., Doran, C., Ferris, J.,Wilkinson, C. (2010). The Range and Magnitude of Alcohol's Harm to Others. Fitzroy, Victoria: AER Centre for Alcohol Policy Research.

McFarlin, S. K., \& Fals-Stewart, W. (2002). Workplace absenteeism and alcohol use: a sequential analysis. Psychology of Addictive Behaviors, 16(1), 17-21.

Neve, R. J., Lemmens, P. H., \& Drop, M. J. (1997). Gender differences in alcohol use and alcohol problems: mediation by social roles and gender-role attitudes. Substance Use \& Misuse, 32(11), 1439-1459.

Norges Offentlige Utredninger (NOU 2004). En ny arbeids- og velferdsforvaltning - om samordning av Aetat, trygdeetaten og sosialtjenestens oppgaver. [Norwegian Official Reports. A new work and welfare administration - about the merger of Aetat, the welfare administration and the social services.] Oslo: Regjeringen.

Nunnally, J. C. (1978). Psychometric theory. New York: McGraw-Hill.

Rise, J., \& Halkjelsvik, T. (2015). Does it matter how you ask? The forbid-allow asymmetry in the measurement of attitudes towards drug policies. International Journal of Drug Policy, 26, 632-635.

Roche, A. M., Pidd, K., Berry, J. G., \& Harrison, J. E. (2008). Workers' drinking patterns: the impact on absenteeism in the Australian work-place. Addiction, 103(5), 738-748.

Schou, L. A. \& Birkelund, G. E. (2015). Alcohol-related sickness absence in young employees in Norway - The impact of social roles and socio-economic status. Nordic Studies On Alcohol and Drugs. Vol 32 (4)

Schou, L. A., \& Moan, I. S. (2015). The Alcohol use - sickness absence association and the moderating role of gender and socio-economic status: A literature review. Drug and Alcohol Review. Downloaded from: http://onlinelibrary.wiley.com/doi/10.1111/dar.12278/abstract

Schou, L. A., Storvoll, E. E., \& Moan, I. S. (2014). Alcohol-related sickness absence among young employees: Gender differences and the prevention paradox. European Journal of Public Health. 24 (3): 480-5

Shi, Y., Sears, L. E., Coberley, C. R., \& Pope, J. E. (2013). The association between modifiable well-being risks and productivity: a longitudinal study in pooled employer sample. Journal of Occupational and Environmental Medicine, 55(4), 353-364.

Upmark, M., Möller, J., \& Romelsjö, A. (1999). Longitudinal, population-based study of self reported alcohol habits, high levels of sickness absence, and disability pensions. Journal of Epidemiology \& Community Health, 53(4), 223-229.

Wilsnack, R. W., Vogeltanz, N. D., Wilsnack, S. C., Harris, T. R., Ahlstrom, S., Bondy, S., Weiss, S. (2000). Gender differences in alcohol consumption and adverse drinking consequences: cross-cultural patterns. Addiction, 95(2), 251-265.

Aaberge, R., \& Laake, P. (1984). Om statistiske teoriar for tolking av data [On theories for statistical interpretation of data. Summary in English]. Tidsskrift for Samfunnsforskning, 25, 165-186. 